\title{
Mexico's Monetary Policy Communication and Money Markets
}

\author{
Alicia Garcia-Herrero ${ }^{1,2}$, Eric Girardin ${ }^{3} \&$ Arnoldo Lopez-Marmolejo ${ }^{4}$ \\ ${ }^{1}$ Senior Fellow, Brussels-Based Think Tank BRUEGEL, Belgium \\ ${ }^{2}$ Adjunct Professor, Hong Kong University of Science and Technology, Hong Kong \\ ${ }^{3}$ Aix-Marseille School of Economics, Aix-Marseille University, France \\ ${ }^{4}$ Inter-American Development Bank \\ Correspondence: Alicia Garcia-Herrero, Hong Kong University of Science and Technology, Hong Kong. E-mail: \\ alicia@ust.hk
}

Received: May 5, 2018

Accepted: December 19, 2018

Online Published: January 10, 2019

doi:10.5539/ijef.v11n2p81

URL: https://doi.org/10.5539/ijef.v11n2p81

\begin{abstract}
Central bank communication is becoming a key aspect of monetary policy. How much financial markets listen and, possibly, understand Banco de Mexico's communication on its monetary policy stance should be a key consideration for the central bank to further modernize its monetary policy toolkit. In this paper, we tackle this issue empirically by using our own index of the tone of communication based on Banco de Mexico's speeches and statements and find that Mexican money markets do not only listen but they also understand the stance of monetary policy conveyed in the central bank's words. Regarding the ability to listen we find that both the volatility and volume in the money market rates change right after communication from Banco de Mexico's governing body. As for the markets' understanding, we document a statistically significant rise in money market rates the more hawkish communication is. All in all, our results show strong evidence of effective oral and written communication from the Central Bank towards Mexico's money markets.
\end{abstract}

Keywords: Mexico monetary policy communication, money market

\section{Introduction}

Central bank communication became topical, due the liberalization of financial markets, for mature as well as emerging market countries. Revived interest in such communication was triggered by the recent widespread attempts by central banks to provide "forward guidance".

In the 1990s, numerous central banks in OECD countries started improving their communication, using different means as a function of their target audience, be it the public or financial markets. With respect to the latter, central banks now publish their own assessment of the economic outlook and even hints to their future monetary policy action (BIS, 2009; Filardo et al., 2008). Academic research (surveyed by Blinder et al., 2008) has provided increasing evidence that communication represents a powerful tool for central banks to conduct a more predictable monetary policy, the more so the more developed the financial system where such monetary policy is conducted. The rationale for such a role of communication lies in the final goal of central bank communication: managing financial markets' expectations, which is easier with forward-looking financial markets (Garcia-Herrero \& Remolona, 2008). Accordingly, central bank communication gets closer to an instrument to conduct monetary policy than a proof of transparency. Thus Svensson (2004) emphasized that, "monetary policy is to a large extent the management of expectations."

As an O.E.C.D. member country, Mexico's monetary policy framework is gradually getting closer to that of its counterparts. This is not only the case for the Banco de Mexico's instruments but also for its communication. The Central Bank of Mexico (Banco de Mexico and Banxico from now on) publishes statements summarizing the meetings of its Monetary Policy Committee (MPC). Its governing body has also become much more active in delivering speeches, which are focused on monetary policy issues and the outlook of the Mexican economy.

Both Banxico's statements and speeches point to a much more transparent central bank but they are not enough to assess how effective the Bank is in communicating its messages to the financial markets. In fact, a central bank can be extremely transparent but markets may not listen to it. It is also conceivable that markets do listen but they do not understand the message. A major implication is that the ability of a central bank to communicate 
should be measured by the reaction of money and financial markets to central-bank messages in the intended direction.

The objective of this paper is to assess whether Mexico's money markets "listen" to Banxico's messages and, possibly, whether they "understand" them. We interpret "listening" as it is generally the case in the literature of central bank communication, namely as the central bank's ability to "move" the markets when making a certain verbal or written statement. A standard way to measure this phenomenon is to assess empirically whether the volatility of interbank rates changes right after a speech from the Central Bank's governing body or the publication of a written statement by its MPC. We also consider the effects of the central bank's words on trade volume in the repo market since this may represent an indirect conduit to volatility, which has been all but neglected in the communication literature.

The use of money market rates to analyze the ability of the central bank to communicate its messages to the financial markets relies on the ground that the money market is highly liquid, is the objective of the monetary policy, and its rates are the leaders for the rest of the interest rates in the economy and the sovereign yield curve.

Examining daily repo rates for the one-day maturity, the most liquid, we do find statistically significant changes in the volatility (measured by the logarithm of the range) and trade volume of such money markets after Banxico's communication is released, so as to confirm the hypothesis that money markets do listen to the Bank both through direct and indirect channels.

Whether money markets understand the Banco de Mexico is a much more demanding question which requires a different empirical strategy. In fact, we need to differentiate across Banxico's messages in terms of their monetary policy stance and see whether money markets react to such announced stance in the right direction. Using high-frequency data, we find strong evidence of a good understanding by market participants of Mexico's central bank statements, measured by money market repo rates increasing immediately after a hawkish statement and the other way round (reduction in rates after dovish statements).

The present study contains three innovative features: First, to the best of our knowledge, it constructs the first comprehensive measure we are aware of Banxico's communication on the monetary policy stance. Such a measure includes both written statements and speeches by Mexican central bank's officials. More importantly, it codes the statements and speeches according to their indication of the monetary policy stance (dovish, neutral or hawkish). The second innovation of the paper is the use of high-frequency data to analyze the impact of the Banco de Mexico communication on the money market (the overnight repo market), well beyond what can be found in the literature. In fact, the paper not only assesses the direct effect of Banco de Mexico communication but also uses microstructure data to analyze the indirect effects of Banco de Mexico communication through trading volume in the money market.

The paper is structured as follows. Section 2 reviews the related literature and describes the paper's objective in some more detail. Section 3 presents the methodology as well as the data compilation, with particular attention to our measure of central-bank communication. It, finally, presents some stylized facts on Mexico's money markets. Section 4 shows our empirical results and interpretations. Finally Section 5 draws some policy conclusions.

\section{Central Bank Communication and Interbank Markets in the Literature}

In an abstract stationary economic environment, with a central bank credibly committed to a policy rule and rational private expectations, no role would be left for central-bank communication (Blinder et al., 2008). In such an environment the private sector would be able to correctly infer from the central bank's observed behavior any systematic pattern in the way monetary policy is conducted (Woodford, 2005) so that central bank communication would be redundant.

A departure from the assumptions underlying such an extreme case should make central-bank communication relevant for policy action. This obviously includes, among other features, non-rational expectations or asymmetric information between the public and the central bank. Mexico departs from the above assumptions since, as most economies, it suffers from information asymmetries and other imperfections. Central-bank communication, or more generally the management of expectations, has become a major policy tool at the disposal of monetary authorities. However, in existing empirical literature, the case of emerging economies has been relatively neglected compared to the available extensive studies for large OECD countries (Blinder et al., 2008). Monetary authorities in emerging economies can only gain from taking advantage of the market-expectations channel, working through the term-structure of interest rates or other means. This might be behind the increasing transparency of central banks in emerging markets.

Therefore, it is not surprising that some evidence for Latin America has begun to emerge. In concrete the case of 
monetary policy communication in Brazil has been analyzed. For example, Caldas (2012) finds evidence that central bank communication, via the minutes of the Monetary Policy Committee meetings, influences the process of expectations formation for interest rates with different maturities. Filho and Rocha (2010) evaluate whether a better communication from the Brazilian Central Bank makes the monetary policy more predictable, concluding that on the decision's release days the interest rates increase, probably indicating that Central Bank communication has a conservative bias, and interest rates volatility decreases.

It is customary for empirical literature on central-bank communication to follow a rather simple approach to assess whether such communication works. Typically, changes in asset prices subsequent to central-bank communication are identified, sometimes controlling for other factors which may affect asset prices (see Blinder et al., 2008 as an example). It is usual to measure Central Bank communication with a dummy variable identifying the moment in which statements (and sometimes even speeches) are published. Increasingly studies go beyond that and code the tone of the speech in terms of the expected monetary policy stance (Ehrman \& Fratzscher, 2007).

When studying the impact of central bank communication, it is important to determine the market on which to measure the impact. The logical first step is to start by the upstream part of the transmission mechanism and focus on the effects of central-bank signals on money markets. From money markets, central bank words should eventually also affect financial markets, including the longer end of the yield curve and even stock markets. In our paper, we shall follow this logical order and focus on the impact of the Banco de Mexico communication on Mexico's money markets.

Beyond the choice of the market, it is also important to consider the different ways in which a certain market may be affected. As previously explained, a weak way to measure the impact of central bank communication would be its effect on volatility (what we call "listening") while a change in the right direction (i.e., in line with the tone of the central bank messages) would imply that the central bank is actually "understood". One more important issue is how changes in expectations triggered by communication translate into trades (i.e., volumes) and not only prices. Indeed, available literature, focusing on the U.S. Treasury bond market's response to FED announcements, stresses that the latter is composed of two distinct stages of adjustment (Fleming \& Remolona, 1999). A short-lived first stage is a response to pure public information. The release of an announcement triggers a large and immediate (ultra-high frequency, such as intraday) price reaction which does not require trading, in as much as it is driven by inventory control. In a prolonged (lower frequency, such as daily) second stage, trading volume surges in a persistent way, due to a disagreement among investors about the implications for prices of the newly-released information. An interesting maintained hypothesis to be tested is, thus, whether communication impacts both the volume and the volatility in the interbank market.

Empirical analysis on the effectiveness of Banco de Mexico's communication on financial markets is scarce, and to our knowledge there are no analyses that incorporate the oral communication, namely the speeches. Related papers include López-Marmolejo (2013) and Herrerías and Gurrola (2012). López-Marmolejo built an index of monetary policy communication based on central bank written statements in order to analyze whether analysts and financial markets' expectations monetary policy reflect an understanding of Banco de Mexico communications' tone. His study considers the period 2005-2011 and finds that Banco de Mexico's communication provides signs to the market that helps it forecast the policy interest rate and that both the financial markets and private economic analysts understand the communication's tone and incorporate such tone into their interest rates expectations. As a result, market expectations on interest rates are more consistent with Banxico's view, and are closer to their finally observed levels. Herrerías and Gurrola (2012) study the reaction of short-term interest rate futures to monetary policy announcements and show that, in a market dominated by institutional investors, trading solely for hedging purposes, the interest rate futures prices are adjusted on announcement dates, not being fully incorporated in advance. They also find that the change to an interest rate operational target modifies the magnitude of the changes in the volatility, volume and prices of the futures contracts resulting from the announcement.

Although not directly related to communication, there are a number of papers on Mexico's monetary policy and interest rates worth reviewing as a way to better choose our control variables. For example, Cermeño et al. (2012) and Torres (2003) study the determinants of the monetary policy rate in Mexico, finding that inflation and output gaps are relevant determinants, and that interest rates are determined "more" by a forward- rather than in a backward-looking behavior. On the determinants of the term structure of interest rates, García-Verdú (2011) finds evidence that some properties of the term structure are associated with macroeconomic variables such as the monetary policy rate and economic activity. 


\section{Methodology and Data}

In order to assess empirically the impact of communication on Mexico's money markets we consider a number of issues. First, as previously mentioned, we differentiate between "listening" and "understanding", by studying separately the effects on volatility and mean interest rate changes. Second, we not only look at direct effects (measured by prices) but also indirect effects through volumes, which have usually been neglected in the communication literature. In addition we carefully choose our data to represent the most active and liquid segment of the Mexican money market, namely the overnight repo market.

\subsection{Methodology}

To evaluate the impact of Banxico communication on Mexico's money markets, we adopt an encompassing approach, using estimates of the mean and volatility equations of the repo overnight rate for the different aspects of communication. As a first step, we focus on whether money markets listen to the Banco de Mexico by assessing empirically whether central bank communication influences the volatility of financial variables, as in Connolly and Kohler (2004) and Ehrmann and Fratzscher (2007). The underlying hypothesis is that the volatility of asset returns should change in as far as there is new - and relevant - information being provided, everything else equal. A more debatable issue is whether volatility should increase or decrease. This very much depends on how much the new information surprises the markets or actually calms them. The latter may be more common if the situation prior to the central bank launching a message was very uncertain. Within the same framework, we also estimate the impact of communication on the volume of the overnight repo market, as an indirect channel affecting volatility.

Measuring volatility has always been a challenging task for financial economists. Previous literature modeling the impact of communication on volatility in the money market has mostly focused on conditional volatility models within a GARCH framework (Blinder et al., 2008). However this only considers the difference in the closing money market rates. In this paper, we go deeper in measuring volatility by using the logarithm of the price range, defined as the difference between the highest and lowest intraday interest rates. The range is a superior volatility proxy to absolute or square returns (Alizadeh, Brandt, \& Diebold, 2002; and Brandt \& Diebold, 2002) since it takes into account the intraday sample path. The range is also less subject to microstructure noise than realized volatility (as championed by Andersen et al., 2001). Furthermore, the logarithm of the range is a preferable measure to the simple range, in particular since it filters out outliers (Brandt \& Diebold, 2002). It is noteworthy that the range may itself show evidence of heteroscedasticity, which will indeed model below.

In a second step, we test whether money markets understand the Banxico's words, following Ehrmanm and Fratzscher (2007). This means that we assess whether our index of the change in the monetary policy stance, based on the Banxico words, affects mean overnight repo rate changes in the intended direction. In other words, we investigate whether hawkish (dovish) communication led to an increase (decrease) in the repo rate. Such an exercise obviously introduces the researcher's subjective judgment and, therefore, a potential measurement error.

Beyond monetary policy communication, we need to control for the key variables which may affect Mexico's money market. The instruments used by the Mexican central bank, which constitute the deeds of monetary policy, are the most important controls since we aim to assess the complementary of words and deeds when conducting monetary policy. In addition, we also include relevant time-series controls, such as seasonality and ad-hoc events.

Regarding monetary policy instruments, we include changes in the policy rate controlled by Banxico $(\triangle \mathrm{PR})$, and net central bank auctions, which represent net liquidity withdrawal (NETA). We control for central bank intervention in the foreign exchange market with a dummy on days of intervention (INTERV). We allow for calendar effects such as end- (WE) and beginning (WB) of-week effects. Finally, we control for key data releases, namely Mexican GDP and CPI announcements with a dummy (MACRO) which takes a value of one on days of GDP growth or inflation releases, and zero otherwise, and similarly for the dummy representing US macro announcements on GDP or CPI (USNEWS). The change in the Fed Funds rate (over periods outside the zero lower bound) was also considered as a control variable but it was not significant and statistical tests such as the Likelihood ratio and the Bayesian Schwarz criterion rejected its inclusion.

Based on all the issues above, we model the repo rate in two ways: the volatility equation (1) and the mean equation (5). Besides, we also estimate a volume (V) equation (4), to investigate the possibility of an indirect channel for central bank communication to affect the money market.

The volatility equation addresses whether money markets listen to the Banxico, using the log range of the 
overnight repo rate as a proxy for volatility. We model the heteroscedasticity of the residuals by using a GARCH model. Controlling for the above-mentioned determinants, the logarithm of the range of the repo rate may be explained as stated in equations (1) and (2) or (3) below:

$$
\begin{aligned}
& \ln \left(\text { range }_{t}=a_{0}+a_{1} \ln \left(\text { range }_{t-1}\right)+a_{2} A \triangle P R_{t}+a_{3} A N E T A_{t}+a_{4} W E_{t}+a_{5} W B_{t}+a_{6} C O M_{t-j}+a_{7} M A C R O_{t}+\right. \\
& U_{\text {SNEWS }}+a_{10} \text { INTERV }_{t}+a_{11} \ln (V)_{t}+\left(h_{t}\right)^{1 / 2} v_{t}
\end{aligned}
$$

with

$$
\left(h_{t}\right)=\eta+\beta\left(h_{t-1}\right)+\alpha\left(v_{t-1}\right)^{2}+\gamma\left(v_{t-1}\right)^{2}
$$

or

$$
\ln \left(h_{t}\right)=\eta+\beta \ln \left(h_{t-1}\right)+\theta / v_{t-1} /\left(h_{t-1}\right)^{1 / 2} /+\lambda\left[v_{t-1} /\left(h_{t-1}\right)^{1 / 2}\right]
$$

Where h denotes conditional variance, the $a$ coefficient is for the ARCH term, and $\beta$ the GARCH term, while $v_{t}$ is a unit-variance, serially uncorrelated, zero mean, i.i.d., error term. In addition, in the threshold GARCH model of Zakoian (1994), (equation 2), bad news (negative residual v) have a different effect $(\alpha+\gamma)$ than good news $(\alpha)$, while in the Exponential GARCH model (equation 3), a negative shock is allowed to exert a larger impact than a positive shock, as in Nelson's (1991). Finally, the letter A before some of the control variables stands for absolute value. As an example, $\mathrm{A} \Delta \mathrm{PR}$ stands for the absolute value of the change in the policy rate. We note $\mathrm{COM}$ the communication variable to be detailed later. Due to the ever-present non-normality in the residuals, we use the Generalized-Error Distribution suggested by Nelson (1991), which encompasses several other distributions depending on the value of the tail-thickness parameter.

An extensive series of work in financial economics provide evidence of a positive correlation between contemporaneous trading volume and volatility. This positive correlation was rationalized initially by Clark (1973), who put forward the Mixture of Distribution Hypothesis (MDH), with further refinements provided by Epps and Epps (1976), Tauchen and Pitts (1983) and Harris and Raviv (1993). The MDH assumes that asset price movement and trading volume are both determined by an unobservable flow of information. In line with the mixture of distribution hypothesis, we thus include daily volume as a potential determinant of volatility.

We now specify the model to estimate the impact of Banxico communication on the transaction volume of the repo market. In this way, we can investigate whether there is an additional indirect effect of communication on the repo market. We use the log of the daily volume of the overnight repo market (V) controlling for the above-mentioned determinants as shown in equations (4) below together with (2) or (3):

$$
\begin{gathered}
\ln \left(V_{t}\right)=b_{0}+b_{1} \ln \left(V_{t-1}\right)+b_{2} A \Delta P R_{t}+b_{3} W E_{t}+b_{4} W B_{t}+b_{5} C O M+b_{6} M A C R O_{t}+a_{7} \text { USNEWS }_{t}+ \\
a_{8} I N T E R V_{t}+\left(h_{t}\right)^{1 / 2} v_{t}
\end{gathered}
$$

where the same notations and specification are used as in equation (1). Lastly, to assess whether money markets understand the Banxico, we model the intraday change in the repo rate (close minus open, noted id, as motivated below) -to be explained by Banxico words as well as deeds and other control variables- as shown in equation (5) below:

$$
\begin{aligned}
& i d_{t}=c_{0}+\sum_{j=1 \text { to } p} c_{1 j} \Delta i d_{t-j}+c_{2} C O M_{t}+c_{3} \Delta P R_{t}+c_{4} \Delta N E T A_{t}+c_{5} W E_{j}+c_{6} W B_{t}+c_{7} M A C R O_{t}+ \\
& a_{8} \text { USNEWS }_{t}+a_{9} \text { INTERV }_{t}+\left(h_{t}\right)^{I / 2} v t \\
& \left(\mathrm{~h}_{\mathrm{t}}\right)=\eta+\beta\left(\mathrm{h}_{\mathrm{t}-1}\right)+\alpha\left(\mathrm{v}_{\mathrm{t}-1}\right)^{2}
\end{aligned}
$$

with the same notations as in equations (1). A GARCH (equation 6) or an EGARCH (equation 3) model will be used since no evidence of a threshold effect was manifest in the conditional variance of the change in the repo rate.

\subsection{Data}

There are two potential problems when evaluating the effectiveness of central bank communication. One is a sample-selection problem and the other one is a potential measurement error. The former is more likely to occur when oral communication is measured by an intermediary, namely newswire reports and not at the source. While newswire are the source used in the existing literature (see Jansen \& De Haan, 2005; and Ehrmann \& Fratzscher 2007), we use Bloomberg and the central bank' website as sources of Banxico speeches.

For the speeches, we focus on the governors of the Banxico, Mr. Guillermo Ortiz and Mr. Agustín Carstens, and the vice-governor Mr. Manuel Sanchez. There are several reasons why we focus on these senior officials. First, in general, the communication of the Banxico has been led by the governor. Mr. Guillermo Ortiz was the governor from december $1^{\text {st }}, 1998$ to end 2009 and Mr. Agustin Carstens replaced him in the position on January $1^{\text {st }}$, 2010. Second, from May 2009, when Mr. Manuel Sanchez was appointed vice-governor, he became an active 
participant in public economic forums. After screening hundreds of reported speeches, we keep 107 by these Board Members. The others are dispelled, being unrelated to monetary policy issues or Mexico's economic outlook. Each speech is selected only once, on the basis of first recording. We construct three variables. The first is a dummy which takes the value of 1 on the day the speech is issued, and zero otherwise (ACOM). The second and third intend to characterize the speech based on its information content. Both variables take a higher value the more hawkish the speech and a lower value the more dovish the speech. Our directional measures of the monetary policy stance is a discrete variable with five possible values: 2 (very hawkish), 1 (hawkish), 0 (neutral), -1 (dovish) or -2 (very dovish). Overall we have 35 speeches with a non-zero coding. In order to construct an encompassing measure of communication, we code written quarterly reports, quasi-monthly decision announcements and their minutes by the Banxico in a similar way to speeches and include in our overall measure of communication (COM dummies) the 136 written statements. It did not prove possible to examine separately the separate effects of speeches and written statements since the latter frequently occur either on the same day or on an adjacent day to speeches.

The monetary policy communication variable (COM) is calculated from January 2005 to August 2013. It begins on the former date for two reasons: i) in 2005 the Bank of Mexico began including in its monetary policy communiqués the monetary interest rate the bank considered consistent with its monetary policy, which makes easier the interpretation of the communication for the financial markets; ii) this was also the year when the central bank began improving considerably its communication policy. For example, the communiqués began having a more homogeneous structure, going from several pages to only one, and more recently to a maximum of two. In addition, from 2005 onwards, the Inflation Reports, the Monetary Program and the Monetary Policy Decision Announcements were scheduled to be published on previously-determined dates.

From Figure 4, it seems that the monetary policy communication measure follows to some extent the interest rate target. But analyzing this relationship requires further analysis which will be implemented in section 4 .

As for the endogenous variable, namely the money market rate, we opt for the repo rate which does remain the benchmark for money market participants. We focus on the collateralized ('Buy Out') repo market, since the uncollateralized part is very narrow and only developed recently. The repo market involves maturities from overnight to more than three months. The relevance of the different maturities can be gauged by examining turnover on the collateralized repo market. As shown in Figure 1, the bulk of volume for such a repo market is concentrated in the low end of the maturity spectrum. In the repo operations, those collateralized by government debt represent around $75 \%$ and those collateralized by debt from banking, corporate and other institutions are around $25 \%$ in 2014. Accordingly we will focus our subsequent analysis only on the shortest maturity, namely the overnight, repo rate (excluding the observations during weekends and holidays). This will also ensure that our estimations do not suffer from an overlapping observation bias since the frequency of our data is also daily.

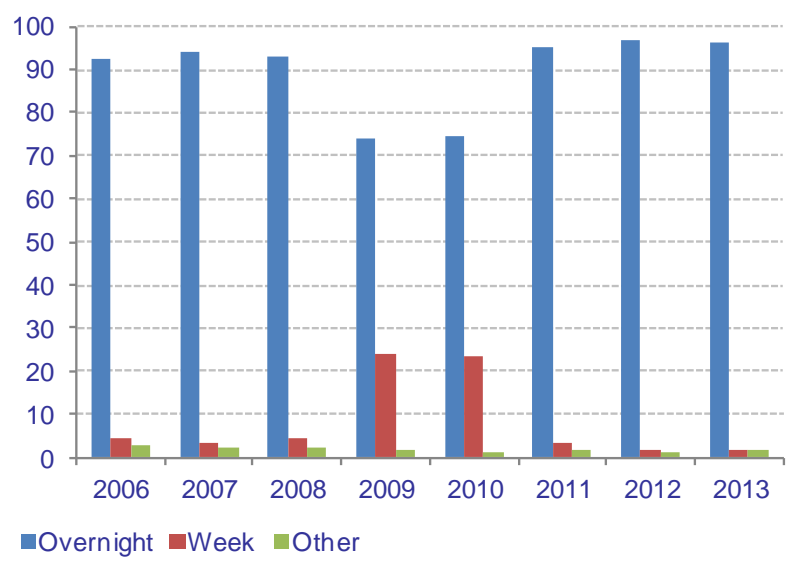

Figure 1. Average share of annual turnover on the repo market by maturity (\%)

Source: Banco de México.

The high and low, as well as open and close, daily quotes of the one-day repo used to compute the range, as well as the intervention days, are extracted from Banxico. The same is true for the daily volume of the one-day repo market and the control variables. The Macro announcements both in US and Mexico are obtained from Bloomberg. 
LRANGEREPO

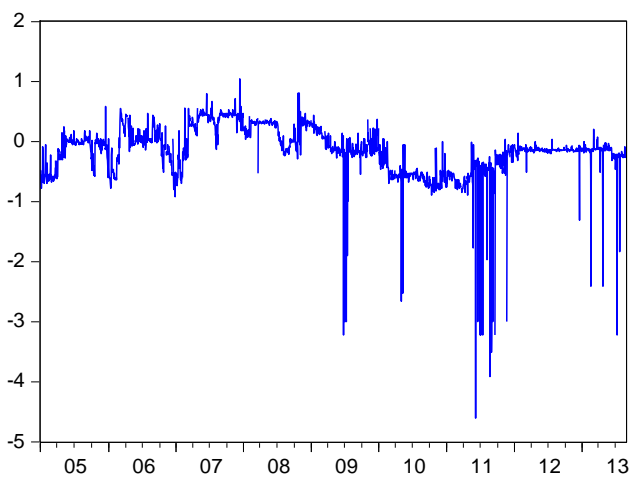

Figure 2. Logarithm of the daily range of the one-day repo $\left(2^{\text {nd }}\right.$ January $2005-27^{\text {th }}$ August 2013)

The daily range of the one-day repo show important movements. Most of the extreme movements seem to occur in periods of economic and financial uncertainty. For example, in the crisis of 2009 Mexico fell into a recession and there was a short-lived episode of perception of counterparty risk in the banking sector; in 2011 risk aversion rose as a result of the European crisis, which in the case of Mexico's money markets could be relevant given the important presence of foreign banks in the banking system; and finally in 2013 there was a strong deceleration in economic activity and a policy rate cut.

Descriptive statistics for the repo rate, the daily range and volume over the full sample as well as subsamples are presented in Appendix 1, Table A.1.

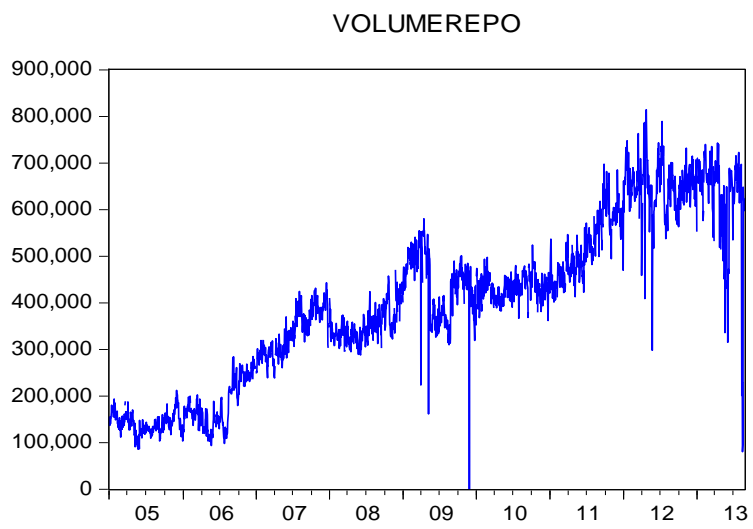

Figure 3. The daily volume of the one-day REPO market ( $2^{\text {nd }}$ January $2005-27^{\text {th }}$ August 2013): number of trades

The volume of transaction in the repo market has been increasing overtime. There was only a pause during the 2008 crisis and in 2013 when the economy decelerated and the central bank cut the monetary rate.

\subsection{Phases in Recent Monetary Policy in Mexico}

In the period September 1995 to January 2008 the Bank of Mexico's objective was banks' balances, also known as "short" or "el corto" in spanish. This mechanism aimed at achieving a certain balance of the aggregate current accounts that the banks hold with the central bank. It is called "short" to refer to a negative aggregate balance objective, and when implementing it, the central bank injects all the liquidity the system needs during the established period, but a share of it, the amount "short" is provided at punitive interest rates. In its first stage, from September 13, 1995 to April 9, 2003, the objective was set in terms of the accumulated balances at the end of month, while in the second stage, from April 10, 2003 to January 20, 2008, the objective became the accumulated balances of the banks at the end of the day. The implementation of monetary policy through a target rate for the overnight interbank operations began on January $21^{\text {st }}, 2008$ (Note 1). Nevertheless, in the periods in which the "short" was used, there was an implicit rate observed, resulting from the decision on the movement in the balance of the current accounts of the banks with the Bank of Mexico, the funding rate. In addition, from August 26, 2005 the monetary policy announcements began including the rates the Bank of Mexico considered consistent with the "short" levels prevailing. Therefore, in the periods when the monetary rate was not explicitly 
fixed, but the balances were, the implicit rate resulting was the interbank offered rate or funding rate. Figure 4 shows the interbank offered rate under different operational mechanisms of monetary policy. As mentioned above, the communication variable is calculated beginning in 2005 because the communication policy improved considerably and has been more homogeneous from this year on, but also because from this same date the monetary rates have been more stable, which improves the ability of financial markets to predict the central bank moves.

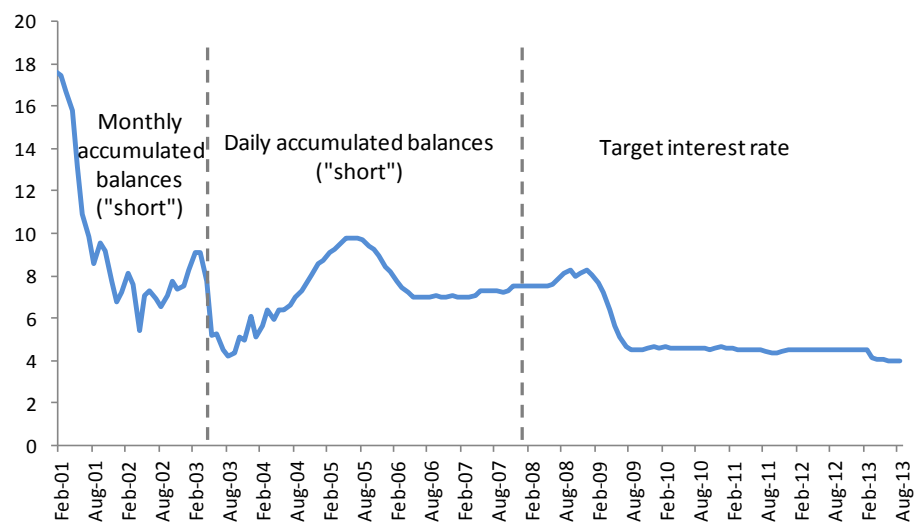

Figure 4. Interbank offered rate under different operational mechanisms of monetary policy

It is important to consider different periods when evaluating the effects of communication on money markets because, as was mentioned above, different operational mechanisms of monetary policy in Mexico were put in place with the aim of increasing transparency, and the communication also had to improve accordingly. For example, one sub-sample analyzed comprises the period when the operational mechanism was "el corto", from January $1^{\text {st }} 2005$ to January $20^{\text {th }}, 2008$, and another is the period when the operational mechanism became a target rate for the overnight interbank interest rate, from January $21^{\text {st }} 2008$ onwards. Also we consider sub-samples accordingly to the economic cycle. In particular, it is important to consider the 2008 crisis that generated a strong recession in 2009 (-4.7\% for annual GDP growth) and financial volatility that generated high economic and financial uncertainty. In terms of GDP growth, the crisis began in the third quarter of 2008 with a quarterly contraction $(-0.1 \%)$. Thus, we separate the sample before and after the 2008 crisis i.e. 2005 to Sept-08 and Jan-2009 onwards.

The stance implied by communication (Figure 5) over these 5 sub-samples matches developments in Mexican inflation and economic growth as plotted in Figure 6. In our modeling of the impact of communication on repo rates, we should leave out overnight (open minus previous day' close) changes, and focus on intraday (close minus same day open) changes since changes in the policy rates are announced at 9:00 am, i.e. half an hour after the market opens, and thus cannot have influenced the overnight repo changes, which took place earlier.

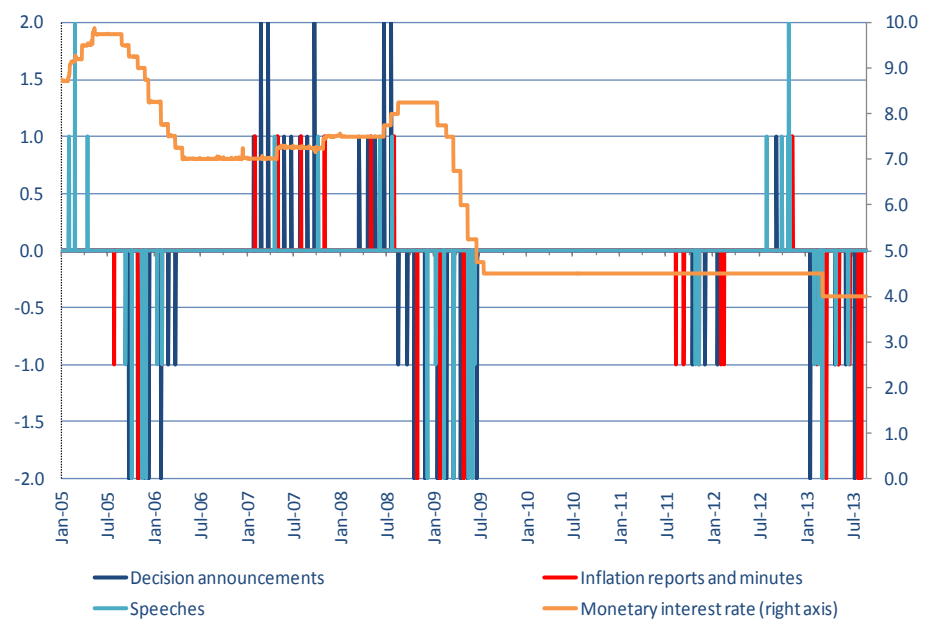

Figure 5. The stance of Mexican monetary policy as indicated by Banxico communication (2nd January 2005-27th August 2013) 


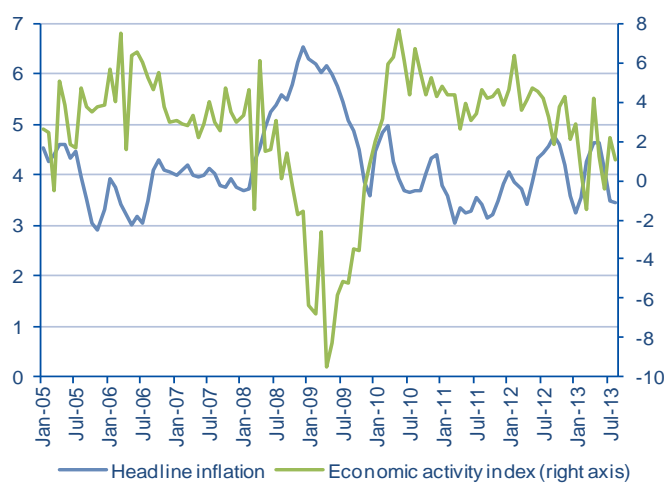

Figure 6. Monthly CPI inflation and economic activity growth (year on year)

Source: National Statistics Institute (INEGI).

\section{Effects of Banxico Communication on Money Markets}

In this section we show the results of our model estimations for the two key questions addressed in this paper, with respect to listening and understanding. For the former, whether monetary markets listen to the Banxico words, we investigate both the direct and indirect channel of influence as already explained.

\subsection{Do Money Markets Listen to the Banxico? Repo Volatility and Volume}

We test the hypothesis that the volatility of repo rate (from equation 1 above) may move in a statistically significant way right after Banxico communication. As far as the expected sign is concerned, existing literature has long preferred to rationalize increases in volatility in response to communication as a confirmation that markets listen to central-bank communication. The underlying justification was that messages from central bankers convey new information and that the latter tends to move markets. Another view, expressed more recently, would rather interpret a fall in volatility as an indication that central bank communication is able to calm markets. The explanation of the latter phenomenon, suggested by Geraats (2002), relies on the presence of a degree of uncertainty before the central bank speaks and also the clarity of its speech. In her view central banks may either confuse markets (increasing volatility) or clarify the situation (reducing it).

Results in Table 1 (Panel A) confirm the hypothesis that money markets listen to the Banxico communication in as far as the daily log range (Note 2) changes in a very significant way right after communication is delivered over all sub-samples from January 2005 to August 2013, which indicates that the Banxico words do convey information that markets perceive as relevant. This is in line with Remolona and Fleming (1999) and Ehrmann and Fratzscher (2007). The sign of the impact on volatility is negative in all cases.

As for the control variables (Appendix 3, Table A3.1), the volatility of the REPO rate moves very significantly only in the most recent subsample when the money rate is changed. Net auctions are effective in influencing volatility, both pre and post the 2008 crisis. However, a change in sign seems to have occurred during 2008, since the effect was negative up to January 2008 and became positive thereafter. Volume raises volatility, but significantly only after May 2006.

Table 1. Effect of Banxico communication on range and volume of repo-rate

\begin{tabular}{lccccc}
\hline & $\begin{array}{c}\text { 02 Jan 2005-21 } \\
\text { Jan 2008 }\end{array}$ & $\begin{array}{c}\text { 02 Jan 2005-12 } \\
\text { Sept 2008 }\end{array}$ & $\begin{array}{c}\text { 02 Jan 2005-05 } \\
\text { May 2006 }\end{array}$ & $\begin{array}{c}\text { 06 May 2006-12 } \\
\text { Sept 2008 }\end{array}$ & $\begin{array}{c}\text { 15 Jan 2009-27 } \\
\text { Aug 2013 }\end{array}$ \\
\hline $\begin{array}{l}\text { Log REPO Range } \\
\text { ACOM (lag 0 to 4) }\end{array}$ & $-0.055^{* * *}$ & $-0.008^{* * *}$ & $-0.054^{*}$ & $-0.0023^{* * *}$ & $-0.014^{* * * *}$ \\
$\begin{array}{l}\text { Log REPO volume } \\
\text { ACOM (lag 0 to 4) }\end{array}$ & -0.04 & $-0.012^{*}$ & $-0.08^{* * *}$ & $-0.018^{* * *}(\mathrm{a})$ & 0.0057 \\
\hline
\end{tabular}

Panel A corresponds to the effects of communication in equation (2) where we do not report the coefficients of control variables (see Appendix 3), and which is estimated jointly with equation (1). Panel B corresponds to the effects of communication in equation (3) where we do not report the coefficients of control variables (see Appendix 3), and which is estimated jointly with equation (4).

The table presents the sum of the coefficient of coded speeches and statements over the current and previous days. The ACOM dummy takes a value of one when a speech or a written statement occur and zero when there is no speech or statement. EGARCH estimation with Generalized Error Distribution. The optimum lag is selected on the basis of Akaike's and Schwartz's Bayesian information criteria. Only significant effects are reported: *** significant at the $1 \%(* * 5 ; * 10 \%)$ on the basis of the z-statistics. (a) The fourth subsample starts in early August 2006 due to the presence of a unit root in the Log volume in the sample starting in May 2006. Only the contemporaneous observation of ACom is significant. 
In Panel A, the estimation in the sample 06 May 2006-12 Sept 2008 considers only two lags of the sum of ACom to maximize its significance on the basis of Akaike's and Schwartz's Bayesian information criteria, but the variable remains significant with the four lags.

Up to the Lehman bankruptcy, communication had a negative effect on volume (Panel B, Table 1), and this effect was often significant. This is in line with the negative response of volatility to communication detected above. By contrast, after Lehman volume seems to have become insensitive to communication. When including the control variables, the range seldom has a significant impact on the volume of the REPO market (Note 3), as shown in panel B of Table 1. This may be due to the fact that some of these variables are themselves determinants of the range (Appendix 3, Table A.3.2). Among the monetary policy instruments used as control variables, central bank auctions had an significant effect only from January 2009. This effect is actually negative on the volume of the REPO market (reinforcing the direct effect found above for volatility). By contrast, the most significant effect of changes in the money rate is apparent over the 2005-Sept. 2008 period, while the effect is only weak thereafter. The significant effect of Macro news appears in the most recent sub-sample. Also a dummy was included in the estimation of the Range in order to control for an outlier on $24^{\text {rd }}$ March 2008. This outlier seems to be the result of an inflation reading above market expectations and an important liquidity reduction by the central bank (almost five times the average for the all sample).

\subsection{Do Money Markets Understand the Banxico?}

As a second step, we regress the mean of repo rate changes (close minus open) on Banxico communication (following equation (5) above). We focus again on the repo with most liquid maturity, the one-day repo. We use the five-category variable constructed to summarize the directional intent and intensity of communication (COM).

Table 2. Effect of Banxico communication on intraday change in REPO-rate

\begin{tabular}{lccccc}
\hline Intraday REPO changes & $\begin{array}{c}\text { 02 Jan 2005-21 } \\
\text { Jan 2008 }\end{array}$ & $\begin{array}{c}\text { 02 Jan 2005-12 } \\
\text { Sept 2008 }\end{array}$ & $\begin{array}{c}\text { 02 Jan 2005-05 } \\
\text { May 2006 }\end{array}$ & $\begin{array}{c}\text { 06 May 2006-12 } \\
\text { Sept 2008 }\end{array}$ & $\begin{array}{c}\text { 15 Jan 2009-27 } \\
\text { Aug 2013 }\end{array}$ \\
\hline $\begin{array}{l}\text { Panel A. With change in policy rate } \\
\text { COM (lag 0 to 4) }\end{array}$ & $0.0024^{* * *}$ & $0.0023^{* * *}$ & $-0.011^{* * *}$ & $0.032^{* * *}$ & $0.038^{* * *}$ \\
$\begin{array}{l}\text { Panel B. With surprise in policy rate } \\
\text { COM (lag 0 to 4) }\end{array}$ & $0.007^{* *}$ & $0.065^{* * *}$ & $0.0075^{*}$ & $0.018^{* * *}$ & $0.038^{* * *}$ \\
\hline
\end{tabular}

This corresponds to the effects of communication in equation (5) (we report the coefficients of control variables in Appendix 3 Table 3.3.3 for panel A and Table A.3.4 for panel B), which is estimated jointly with equation (6). Close minus open repo in all cases in the mean equation. The COM dummy for communication and the SPEECH dummy for speeches only has a FIVE-pronged classification as very dovish (-2), dovish (-1), neutral (0), hawkish (+1), and very hawkish (+2). These dummies are included alternatively in the equation. GARCH estimation with Generalized Error Distribution. Only significant effects are reported: *** significant at the $1 \%$ on the basis of the z-statistics. In the sample 02 Jan 2005-05 May 2006 only the sum of advances from 1 to 5 of Com are significant, suggesting probably expectations on the communication.

We find highly-significant changes in the repo rates after the delivery of oral and written communication (Table 2, row 1). In other words, the more hawkish the communication by Mexico's central bankers, the larger tends to be the immediate rise in the REPO rate during the day. In fact, the result holds for all subsamples, except for an initial negative influence. These results show that Mexico's money market does pay good attention to the Banxico's communication and understand its messages.

When looking at monetary policy instruments, the common feature is the contrast between the pre- and post-January 2009 subsamples. Even though changes in the money rate have a consistent positive impact across subsamples, that effect almost doubles in the second subsample, starting in January 2009. However, such a rise occurs even earlier, as testified by the sample starting in May 2006. With respect to auctions, the contrast between subsamples is of a different nature, since the effect on the repo rate is negative in the first subsample, but becomes positive also after May 2006. Recall NETA corresponds to liquidity withdrawal, computed as Deposit auction minus Liquidity auction, where Deposit auction reduces liquidity and Liquidity auction increases it. We thus expect a Net Liquidity Withdrawal to increase rates and therefore a positive coefficient. A positive coefficient multiplied by a negative NETA variable (i.e. more liquidity = Liquidity auction larger than the Deposit auction) should generate lower rates. Therefore, the positive signs after May 2006 seems reasonable and comprises most of the sample (only 2005 is left out), including the most recent period, a period when inflation began staying more regularly below $4 \%$ (the upper part of the central bank's target) and the rates took a downward trend (moving away permanently from the levels around $10 \%$ ). 
In the Repo change estimation dummies were also included to account for a few outliers. These outliers are in general associated with relevant surprises in inflation, both in Mexico $\left(10^{\text {th }}\right.$ May $2005,24^{\text {rd }}$ and $25^{\text {th }}$ April 2006, $23^{\text {rd }}$ July 2009) and the US ( $15^{\text {th }}$ December $2005,17^{\text {th }}$ January $2007,15^{\text {th }}$ August 2007), and in one occasion with a surprise in US GDP growth (26 ${ }^{\text {th }}$ April 2013).

\subsection{Robustness}

One could argue that we should control not for the change in the policy rate but rather its surprise component, i.e. the excess of the actual versus expected policy rate. Accordingly, we reestimate our mean model substituting the latter for the former control variable. As shown in Panel B of Table 2, the impact of communication on the intraday change in the repo rate is unchanged, except for the welcome fact that the surprising negative effect in the initial subperiod (2005-2006), with the change in the policy rate as control variable, is replaced by, a much more intuitive, positive effect with the surprise as control.

Over the second major subsample (2009-2013) the surprise component of the policy rate has almost the same positive and significant effect on the change in the intraday repo rate than the actual change in the policy rate. However, while a similar positive effect was valid for all previous subsamples with the change of policy rate as control, a positive, though insignificant, effect remains only in two subsamples (Jan 2005 though Sept 2008 or May 2006), while a negative effect appears over the other two (January 2005-January 2008 and May 2006-Sept 2008), and it is significant and substantial only in the latter subperiod.

\section{Conclusions}

This paper provides the first evidence of the ability of Banxico communication to steer money markets. We focus on the most liquid segment of the REPO market, the one-day maturity and cover an 8 year period (from early 2005 to the summer of 2013). For Banxico communication we build an indicator of the tone of monetary policy based on the speeches delivered by Banxico senior officials but we also control for MPC written statements.

As a first step, we provide evidence that money market operators do listen to Banxico, since its communication generates changes in market volatility (measured by the log range) in a significant way. This result is similar to those previously found for the U.S., the U.K., and some other O.E.C.D. countries (Kohn \& Sack, 2004; or Connolly \& Kohler, 2004; and Reeves \& Savicki, 2007). Going beyond that literature, we also quantify the influence of Banxico communication on the money market transaction volume. We conclude that volume also responds significantly to communication, strengthening our prior that Mexican money markets do listen to the central bank.

As a second step we address a more elaborate question, namely whether money markets understand Banxico's words. In particular we test empirically whether money markets perceive the stance of monetary policy which the Banxico intends to convey in its speeches or written statements. Our findings imply that intraday REPO rate changes generally respond to Banxico's communication in the expected direction, namely more hawkish communication leads to increases in money market rates. Such a finding is robust when we control either for relevant factors such as the actual (or the surprise) changes in monetary policy (i.e., in the policy rate) and for macroeconomic news both in Mexico and in the US.

In sum, we conclude that Banxico words (and not only deeds) have a significant impact on Mexico's money market both in direct and indirect ways. Furthermore, Mexican money market participants not only react to the Banxico words but also appear to understand the directional intent of Banxico statements and speeches. These findings can be interpreted as the Banxico being a very predictable central bank, since they are similar to those for peer central banks in larger O.E.C.D. economies, such as the U.S., the U.K. and the euro area.

\section{Acknowledgements}

We thank Marco Basulto and Alfredo Acosta for excellent research assistance and Enestor dos Santos and Carlos Serrano for their comments. All remaining errors are ours. Finally, the opinions expressed are those of the authors' and not necessarily those of NATIXIS or IADB.

\section{References}

Alizadeh, S., Brandt, M. W., \& Diebold, F. X. (2002). Range-based Estimation of Stochastic Volatility Models. Journal of Finance, 57(2), 1047-1090. https://doi.org/10.1111/1540-6261.00454

Andersen, T. G., Bollerslev, T., Diebold, F. X., \& Ebens, H. (2001). The Distribution of Realized Stock Return Volatility. Journal of Financial Economics, 61, 43-76. https://doi.org/10.1016/S0304-405X(01)00055-1

BIS. (2009). Communication of Monetary Policy Decisions by Central Banks: What is Revealed and Why? BIS papers, 47, May. 
Blinder, A. S., Ehrmann, M., Fratzscher, M., De Haan, J., \& Jansen, D. J. (2008). Central Bank Communication and Monetary Policy: A survey of theory and evidence. Journal of Economic Literature, 46(4), 910-945. https://doi.org/10.1257/jel.46.4.910

Boschen, J. F., \& Mills, L. O. (1995). The Relation between Narrative and Money Market Indicators of Monetary Policy. Economic Inquiry, 33(1), 24-44. https://doi.org/10.1111/j.1465-7295.1995.tb01844.x

Brandt, M. W., \& Diebold, F. X. (2002). A no-Arbitrage Approach to Range-based Estimation of Return Covariances and Correlations. Working Paper, University of Pennsylvania.

Brunner, K. (1981). The Art of Central Banking. Center for Research in Government Policy and Business, University of Rochester, Working Paper GPB 81-6.

Caldas, G. (2012). Financial Market Reaction to Central Bank Monetary Policy Communications under an Inflation-Targeting Regime: The Case of Brazil. CEPAL Review, 107, 165-81.

Cermeño, R., Villagomez, A., \& Orellana, J. (2012). Monetary Policy Rules in a Small Open Economy: An Application to Mexico. Journal of Applied Economics, 15(2), 259-86. https://doi.org/10.1016/S1514-0326(12)60012-9

Connolly, E., \& Kohler, M. (2004). News and Interest Rate Expectations: A Study of Six Central Banks. In C. Kent, \& S. Guttman (Eds.), The Future of Inflation Targeting (pp. 108-34). Sydney: Reserve Bank of Australia.

Ehrmann, M., \& Fratzscher, M. (2007). Communication by Central Bank Committee Members: Different Strategies, Same Effectiveness? Journal of Money, Credit, and Banking, 39(2-3), 509-41. https://doi.org/10.1111/j.0022-2879.2007.00034.x

Elliott, C., Rothenberg, T. J., \& Stock, J. H. (1996). Efficient Tests for an Autoregressive Unit Root. Econometrica, 64, 813-836. https://doi.org/10.2307/2171846

Elliott, G. (1999). Efficient Tests for a Unit Root when the Initial Observation is Drawn from its Unconditional Distribution. International Economic Review, 44, 767-784. https://doi.org/10.1111/1468-2354.00039

Filho, C., \& Rocha, F. (2010). Como o mercado de juros futuros reage a comunicacao do Banco Central? Economia Aplicada/Brazilian Journal of Applied Economics, 14(3), 265-92.

Fleming, J. M., \& Remolona, E. M. (1999). Price Formation and Liquidity in the U.S Treasury Market: The Response to Public Information. Journal of Finance, 54(5), 1901-1915. https://doi.org/10.1111/0022-1082.00172

Garcia-Herrero, A., \&Remolona, E. (2008). Managing Expectations by Words and Deeds: Monetary Policy in Asia and the Pacific. BBVA, Economic research department, Working Paper, 0805. https://doi.org/10.2139/ssrn.1457506

García-Verdú, S. (2011). Algunas Consideraciones Sobre la Estructura Temporal de Tasas de Interés del Gobierno en México. Banco de México Working Paper 2011-18.

Geraats, P. (2002). Central Bank Transparency, Economic Journal, 112, 532-565. https://doi.org/10.1111/1468-0297.00082

Hansen, B. E. (1994). Autoregressive conditional density estimation. International Economic Review, 35, 705-730. https://doi.org/10.2307/2527081

Herrerías, R., \& Gurrola, P. (2012). Monetary Policy Announcements and Short-Term Interest Rate Futures Volatility: Evidence from the Mexican Market. International Finance, 15(2), 225-50. https://doi.org/10.1111/j.1468-2362.2012.01303.x

Jansen, D. J., \& De Haan, J. (2005). Talking Heads: The Effects of ECB Statements on the Euro-Dollar Exchange Rate. Journal of International Money and Finance, 24(2), 343-361. https://doi.org/10.1016/j.jimonfin.2004.12.009

Kohn, D. L., \& Sack, B. (2004). Central Bank Talk: Does it Matter and Why? In Macroeconomics, Monetary Policy, and Financial Stability (pp. 175-206). Ottawa: Bank of Canada.

Kwaitkowski, D., Phillips, P. C. B., Schmidt, P., \& Shin, Y. (1992). Testing the Null Hypothesis of Stationarity against the Alternative of a Unit Root. Journal of Econometrics, 54, 159-78. https://doi.org/10.1016/0304-4076(92)90104-Y

López-Marmolejo, A. (2013). Deciphering Banco de Mexico’s language (in spanish). El Trimestre Económico, 
80(2), 7-32.

Nelson, D. B. (1991). Conditional Heteroskedasticity in Asset Returns: A New Approach. Econometrica, 59, 347-370. https://doi.org/10.2307/2938260

Ng, S., \& Perron, P. (2001). Lag Length Selection and the Construction of Unit Root Tests with Good Size and Power. Econometrica, 69, 1519-1554. https://doi.org/10.1111/1468-0262.00256

Reeves, R., \& Sawicki, M. (2007). Do Financial Markets React to Bank of England Communication? European Journal of Political Economy, 23(1), 207-27. https://doi.org/10.1016/j.ejpoleco.2006.09.018

Rosa, C., \& Verga, G. (2007). On the Consistency and Effectiveness of Central Bank Communication: Evidence from the ECB. European Journal of Political Economy, 23(1), 146-75. https://doi.org/10.1016/j.ejpoleco.2006.09.016

Sebestyen, S., \& Sicilia, J. (2005). Is the External Communication of the European Central Bank Effective? University of Alicante, Working Paper, November.

Taylor, J. B. (1993). Discretion versus Policy Rules in Practice. Carnegie Rochester Conference Series on Public Policy, 39, 195-214. https://doi.org/10.1016/0167-2231(93)90009-L

Torres, A. (2003). Monetary Policy Rules as a Nominal Anchor: Evidence from the Mexican Economy. Central Bank Award "Rodrigo Gomez 2002": CEMLA.

Woodford, M. (2005). Central-Bank Communication and Policy Effectiveness. In The Greenspan Era: Lessons for the Future (pp. 399-474). Kansas City: Federal Reserve Bank of Kansas City. https://doi.org/10.3386/w11898

Zakoian, J. M. (1994). Threshold heteroscedastic Models. Journal of Economic Dynamics and Control, 18, 931-944. https://doi.org/10.1016/0165-1889(94)90039-6

\section{Notes}

Note 1. The interbank offered rate (tasa de fondeo bancario) is the operational objective of the monetary policy. It is the rate for wholesale operations in the interbank market that use bank debt securities as a collateral. It is overnight.

Note 2. Unit root tests reported in Table A2 of the Appendix document that the unit root is rejected for the logarithm of the range and of the volume, as well as for the close minus open repo rate.

Note 3 . In a model where only lagged values of the log volume are included, the one-day lagged log range has the following coefficients over the five samples considered here: (I) $0.03 *$; (II) $0.113^{* * *}$; (III) $0.28 * * *$; (IV) $-0.312 * * * ;(\mathrm{V}) 0.056$.

\section{Appendix 1. Descriptive statistics and unit-root tests}

Table A1. Descriptive statistics on repo rate, range and volume

\begin{tabular}{|c|c|c|c|c|c|}
\hline & $\begin{array}{c}\text { 02 Jan 2005-21 } \\
\text { Jan } 2008\end{array}$ & $\begin{array}{c}\text { 02 Jan 2005-12 } \\
\text { Sept 2008 }\end{array}$ & $\begin{array}{c}\text { 02 Jan 2005-05 } \\
\text { May 2006 }\end{array}$ & $\begin{array}{l}\text { 06 May 2006-12 } \\
\text { Sept 2008 }\end{array}$ & $\begin{array}{c}15 \text { Jan 2009-27 } \\
\text { Aug 2013 }\end{array}$ \\
\hline \multicolumn{6}{|c|}{ Repo-rate intraday change (close-open) } \\
\hline Mean & -0.03 & -0.03 & -0.019 & -0.037 & -0.02 \\
\hline Std. dev & 0.106 & 0.101 & 0.093 & 0.105 & 0.089 \\
\hline Skewness & -3.19 & -3.31 & 1.91 & -5.38 & -1.70 \\
\hline Kurtosis & 49.3 & 51.3 & 22.2 & 60.1 & 33.4 \\
\hline \multicolumn{6}{|c|}{ Log Range } \\
\hline Mean & 0.0014 & 0.032 & -0.166 & 0.146 & -0.346 \\
\hline Std. dev & 0.354 & 0.338 & 0.314 & 0.296 & 0.477 \\
\hline Skewness & -0.328 & -0.497 & -0.07 & -0.85 & -4.16 \\
\hline Kurtosis & 2.317 & 2.503 & 2.22 & 3.84 & 26.3 \\
\hline \multicolumn{6}{|c|}{ Log Volume } \\
\hline Mean & 12.2 & 12.31 & 11.9 & 12.55 & 13.1 \\
\hline Std. dev & 0.42 & 0.43 & 0.16 & 0.32 & 0.23 \\
\hline Skewness & 0.17 & -0.19 & -0.30 & -1.49 & -1.03 \\
\hline Kurtosis & 1.67 & 1.56 & 3.08 & 4.66 & 8.51 \\
\hline
\end{tabular}

Computed with data extracted from Banco de Mexico. 
Table A2. Unit root tests

\begin{tabular}{lccccc}
\hline Ng-Perron (2001) test & $\begin{array}{c}\text { 02 Jan 2005-21 } \\
\text { Jan 2008 }\end{array}$ & $\begin{array}{c}\text { 02 Jan 2005-12 } \\
\text { Sept 2008 }\end{array}$ & $\begin{array}{c}\text { 02 Jan 2005-05 } \\
\text { May 2006 }\end{array}$ & $\begin{array}{c}\text { 06 May 2006-12 Sept } \\
\text { 15 Jan 2009-27 }\end{array}$ & \begin{tabular}{c} 
Aug 2013 \\
\hline Repo-rate intraday change
\end{tabular} \\
$\begin{array}{l}\text { MZt } \\
\text { Log Range }\end{array}$ & $-13.82^{* * *}$ & $-15.2^{* * *}$ & $-8.83^{* * *}$ & $-11.6^{* * *}$ & $-9.93^{* * * *}$ \\
MZt & & & & $-4.49^{* * *}$ & $-12.1^{* * *}$ \\
Log Volume & $-5.08^{* * *}$ & $-4.91^{* * *}$ & $-3.68^{* * *}$ & & $-10.2^{* * * *}$ \\
MZt & & & & $-4.32^{* * *}(\mathrm{a})$ & $-5.44^{* * *}$ \\
\hline
\end{tabular}

With constant and trend. Null hypothesis: series has a unit root. HAC (Andrews) corrected variance (Parzen kernel). The MZt statistics has the same distribution as the ADF-t statistics. Critical values: MZt: -3.12 (1\%), -2.91 (5\%), -2.62 (10\%). (a) 17 August 2006-12 September 2008 while a unit root is accepted on the sample starting in May 2006.

\section{Appendix 2. Examples of reports and their coding}

Monetary policy announcement on January18, 2013

The growth rate of economic activity in Mexico has slowed. In this environment, the output gap has remained near zero. In addition, the labor market has continued showing a recovery. However, downside risks for the Mexican economy persist as a reflection of macroeconomic imbalances.

In recent months, headline inflation in Mexico continued declining significantly to close 2012 below 4 percent, as the Bank of Mexico anticipated. Annual core inflation fell to settle at 2.90 percent in December, a historically low level. It is expected that in 2013, annual headline inflation will fall below the levels recorded in 2012 and close to the permanent objective of 3 percent. In the case of annual core inflation it is anticipated that it will locate below 3 percent. In sum, it is considered that the balance of risks for inflation has improved.

If the environment described consolidates it could be advisable to reduce the objective of the overnight interbank interest rate to facilitate the adjustment of the economy to a state of lower economic growth and lower inflation.

Coded: -2 .

Monetary policy announcement on April 6, 2013

Derived from the slowdown in the global economy, various indicators of economic activity in Mexico have registered a slowdown. External demand and some consumption indicators continue to show signs of weakness. In sum, downside risks to economic activity in Mexico prevail, derived mainly from the possibility that the recent slowdown in the U.S. economy could intensify.

Annual headline inflation in Mexico in March and the first half of April registered a major hike following a higher incidence of the non-core component. This increase was influenced by effects of the CPI base of comparison, as the Bank of Mexico had anticipated, and by the occurrence of clearly identified supply shocks. The process of price formation has not been affected and remains consistent with the convergence of inflation to the target of 3 percent. This is evident in the performance of core inflation, which has remained very close to 3 percent as a result of two factors.

Coded: 0.

Monetary policy announcement on June 20, 2008.

Inflationary pressures have intensified in the world due to a sharp increase in the prices of food, energy and other commodities. Virtually all central banks have revised up their inflation forecasts. Some, in the main developed countries, have expressed growing concerns about the inflationary deterioration; others, in many emerging economies, have tightened their monetary policy.

During the first quarter, economic activity in Mexico did not suffer significantly from the weakening of the U.S. economy.

The recent dynamics of inflation are worrying because it responds to the stress of the same external pressures that have been commented in the past. So, like most central banks, the Bank of Mexico has had to revise upwards its inflation projections. It is also likely that some disparities between certain domestic prices and their world benchmarks will gradually correct. Mexico shows no inflationary pressures on the demand side. Even an eventual weakening of aggregate expenditure could be a factor that would mitigate upward pressures. Inflation expectations over the medium term remain well anchored, and contamination of the prices not related with the 
hike of commodity prices has been limited. However, the balance of risks to inflation has worsened. The path of inflation for the rest of the year and early 2009 could be somewhat higher than expected in the latest Inflation Report.

Coded: 2.

\section{Appendix 3. Detailed estimation results}

Table A.3.1. (Log) Range

\begin{tabular}{|c|c|c|c|c|c|}
\hline & $\begin{array}{c}\text { 02 Jan 2005-21 } \\
\text { Jan 2008 } \\
\end{array}$ & $\begin{array}{c}\text { 02 Jan 2005-12 } \\
\text { Sept } 2008 \\
\end{array}$ & $\begin{array}{c}\text { 02 Jan 2005-05 } \\
\text { May 2006 } \\
\end{array}$ & $\begin{array}{c}06 \text { May 2006-12 } \\
\text { Sept 2008 } \\
\end{array}$ & $\begin{array}{c}\text { 15 Jan 2009-27 } \\
\text { Aug 2013 } \\
\end{array}$ \\
\hline \multicolumn{6}{|l|}{ Mean } \\
\hline Cst & $-0.126^{* * *}$ & $-0.103 * * *$ & 0.106 & $-0.136^{* * * *}$ & $-0.157 * * *$ \\
\hline$\sum \mathrm{AR}$ (1 to 12$)$ & $0.945^{* *}$ & $0.89 * * *$ & $0.97 * * *$ & $0.97 * * *$ & $0.96^{* * *}$ \\
\hline Macro & $0.012 * * *$ & $0.0096^{* * *}$ & 0.004 & $0.00066^{*}$ & $0.003 * * *$ \\
\hline LV & 0.018 & $0.008^{* * * *}$ & -0.0009 & $0.011 * * *$ & $0.011 * * *$ \\
\hline $\mathrm{A} \triangle \mathrm{PR}$ & $0.064^{*}$ & 0.036 & 0.094 & 0.017 & $-0.056^{* * *}$ \\
\hline NETA & $-4.40 \mathrm{E}-07 * *$ & $6.79 \mathrm{E}-07 *$ & 6.85 E-07 & $1.05 \mathrm{E}-07$ & $5.24 \mathrm{E}-06^{* * *}$ \\
\hline Friday & $-0.007 * *$ & -0.007 & $-0.029 * * *$ & 0.0027 & 0.0013 \\
\hline Monday & 0.003 & $0.008 * * *$ & -0.0012 & $0.009 * * *$ & -0.0017 \\
\hline$\sum$ ACom $(0$ to -4$)$ & $-0.055^{* * * *}$ & $-0.008 * *$ & $-0.054 * *$ & $-0.023 * * *$ & $-0.014 * * *$ \\
\hline US News & $0.0153 * * *$ & $-0.015 * * *$ & $0.0290 * * *$ & $0.012 * * *$ & $0.006^{* * * *}$ \\
\hline US News(-1) & $0.0157 * * *$ & $-0.007^{*}$ & -0.0239 & - & $-0.01 * * *$ \\
\hline Dum032408 & & $-0.923 * * *$ & & & \\
\hline \multicolumn{6}{|l|}{ Variance } \\
\hline$\eta$ & $-0.47 * *$ & $-0.47 * * *$ & $-0.826^{* * * *}$ & $0.0007 * * *$ & $-0.469 * * *$ \\
\hline$\theta(-1)$ & $0.81 * * *$ & $0.783 * * *$ & $0.973 * * *$ & & $0.727 * * *$ \\
\hline$\theta(-2)$ & $-043^{* * *}$ & $-0.425 * * *$ & $-0.375^{*}$ & & $-0.259 * * *$ \\
\hline$\lambda \operatorname{Resid}(-1)$ & $-0.24 * * *$ & $-0.210^{*}$ & $-0.252 * *$ & & $0.234 * * *$ \\
\hline$\beta(-1)$ & $0.938 * * *$ & $0.941 * * *$ & 0.89 *** & $0.67 * * *$ & $0.947 * * *$ \\
\hline$\delta(-1)$ & & & & $0.176^{* * *}$ & \\
\hline$\gamma$ & & & & $0.558 * * * *$ & \\
\hline GED & $0.73 * * *$ & $0.719 * * *$ & $0.88^{* * *}$ & $0.769 * * *$ & $0.558 * * *$ \\
\hline Adj R2 & 0.833 & 0.846 & 0.787 & 0.820 & 0.127 \\
\hline $\mathrm{AR}$ & $14.5[0.15]$ & $14.3[0.16]$ & $6.87[0.74]$ & $10.8[0.37]$ & 8.58 [0.57] \\
\hline $\mathrm{ARCH}$ & $0.54[0.45]$ & $0.50[0.47]$ & $0.28[0.59]$ & $0.02[0.89]$ & $0.02[0.87]$ \\
\hline
\end{tabular}

*** Z-statistic significant at $1 \%$ level (** 5\%; * 10\%). This corresponds to the estimation of equation (1) and (2) or (3) in the text with corresponding definitions of variables and parameters. The estimation in the sample 06 May 2006-12 Sept 2008 considers only two lags of the sum of ACom to maximize its significance on the basis of Akaike's and Schwartz's Bayesian information criteria, but the variable remains significant with the four lags.

Table A.3.2. (Log) Volume

\begin{tabular}{|c|c|c|c|c|c|}
\hline & $\begin{array}{c}\text { 02 Jan 2005-21 } \\
\text { Jan } 2008 \\
\end{array}$ & $\begin{array}{c}\text { 02 Jan 2005-12 } \\
\text { Sept } 2008\end{array}$ & $\begin{array}{c}\text { 02 Jan 2005-05 } \\
\text { May } 2006\end{array}$ & $\begin{array}{l}17 \text { Aug. 2006-12 } \\
\text { Sept } 2008\end{array}$ & $\begin{array}{c}\text { 15 Jan 2009-27 } \\
\text { Aug 2013 }\end{array}$ \\
\hline \multicolumn{6}{|l|}{ Mean } \\
\hline Cst & $0.066^{* * *}$ & $0.140 * *$ & $1.80^{* * *}$ & $0.513 * * *$ & 0.092 \\
\hline$\sum \mathrm{AR}(1$ to 10$)$ & $0.98 * *$ & $0.965 * * *$ & $0.84^{* * *}(1$ to 4$)$ & $0.93 * * *$ & $0.97 * * *$ \\
\hline Macro & 0.0032 & -0.007 & 0.010 & $-0.013^{*}$ & $0.013 * * *$ \\
\hline $\mathrm{A} \Delta \mathrm{PR}$ & 0.082 & $0.121 * *$ & 0.086 & $0.2615 * *$ & $0.049 *$ \\
\hline NETA & $-6.45 \mathrm{E}-08$ & -2.06 E-07 & $6.13 \mathrm{E}-07$ & -1.63 E-07 & $-1.04 \mathrm{E}-07 * *$ \\
\hline Friday & $-0.012 *$ & -0.006 & -0.003 & -0.0031 & $-0.014 * * *$ \\
\hline Monday & $-0.03 * * *$ & $-0.021 * * *$ & $-0.026^{* *}$ & $-0.016^{* *}$ & $-0.0015^{* * *}$ \\
\hline$\sum$ ACom $(0$ to -4$)$ & -0.004 & $-0.003^{*}$ & $0.078 * *$ & $-0.018 * *$ & $0.0057 * *$ \\
\hline US News & -0.006 & -0.007 & & -0.006 & 0.0006 \\
\hline US News(-1) & -0.0014 & 0.0067 & & 0.0003 & -0.005 \\
\hline
\end{tabular}




\begin{tabular}{|c|c|c|c|c|c|}
\hline \multicolumn{6}{|l|}{ Variance } \\
\hline$\eta$ & $-0.21 * *$ & $-0.221 * * *$ & 0.008 & 0.0006 & $-1.28 * * *$ \\
\hline$\theta(-1)$ & $0.104 * * *$ & $0.148 * * *$ & & 0.035 & $0.305^{* * *}$ \\
\hline$\theta(-2)$ & - & -0.006 & & & - \\
\hline$\lambda \operatorname{Resid}(-1)$ & $-0.07 * * *$ & $-0.045^{*}$ & & & $-0.104 * * *$ \\
\hline$\beta(-1)$ & $0.972 * * *$ & $0.977 * * *$ & $0.86^{* * *}$ & 0.77 *** & $0.792 * * *$ \\
\hline$\delta(-1)$ & & & 0.064 & & \\
\hline$\gamma$ & & & & 0.074 & \\
\hline GED & $1.31 * * *$ & $1.39 * * *$ & $1.26^{* * *}$ & $1.63 * * *$ & $0.917 * * *$ \\
\hline Adj R2 & 0.953 & 0.836 & 0.573 & 0.87 & 0.733 \\
\hline $\mathrm{AR}(12)$ & 6.34 [0.77] & $2.81[0.98]$ & $6.44[0.77]$ & $4.02[0.98]$ & $12.5[0.25]$ \\
\hline ARCH-LM & $0.34[0.56]$ & $0.056[0.81]$ & $0.99[0.31]$ & $0.01[0.90]$ & $0.03[0.86]$ \\
\hline
\end{tabular}

*** Z-statistic significant at $1 \%$ level (** 5\%; * 10\%). The fourth subsample starts in August 2006 due to the presence of a unit root in the Log volume on the sample starting in May 2006. This corresponds to the estimation of equation (4) and (2) or (3) in the text with corresponding definitions of variables and parameters. In the sample 17 Aug. 2006-12 Sept 2008 only the contemporaneous observation of ACom is significant.

Table A.3.3. Repo change (Log Close minus log Open rate) with change in policy rate

\begin{tabular}{|c|c|c|c|c|c|}
\hline & $\begin{array}{c}\text { 02 Jan 2005-21 } \\
\text { Jan 2008 } \\
\end{array}$ & $\begin{array}{c}\text { 02 Jan 2005-12 } \\
\text { Sept } 2008 \\
\end{array}$ & $\begin{array}{c}\text { 02 Jan 2005-05 } \\
\text { May 2006 } \\
\end{array}$ & $\begin{array}{c}\text { 06 May 2006-12 } \\
\text { Sept 2008 } \\
\end{array}$ & $\begin{array}{c}15 \text { Jan 2009-27 } \\
\text { Aug 2013 }\end{array}$ \\
\hline \multicolumn{6}{|l|}{ Mean } \\
\hline Cst & $-0.0067 * * *$ & $-0.018^{* * *}$ & $0.0073 * * *$ & $-0.023^{* * *}$ & $-0.0118 * * *$ \\
\hline$\sum \mathrm{AR}$ (1 to $\left.\mathrm{n}\right)$ & $0.028 * * *(4)$ & $0.008^{* * *}(6)$ & $0.256^{* *}(7)$ & $-0.009^{* *}(7)$ & $0.2154 * * *(6)$ \\
\hline Macro & 0.0017 & -0.011 & $-0.0099 * * *$ & -0.003 & 0.003 \\
\hline$\Delta \mathrm{PR}$ & $0.07 * * *$ & $0.096 * * *$ & $0.096 * * *$ & $0.172 * * *$ & $0.164 * * *$ \\
\hline NETA & $-6.43 \mathrm{E}-07 * * *$ & $-7.32 \mathrm{E}-08 * *$ & $-1.24 \mathrm{E}-06^{* * * *}$ & $1.95 \mathrm{E}-08 * * *$ & $1.20 \mathrm{E}-07 *$ \\
\hline Friday & $-0.0053^{* * *}$ & -3.17 E-05 & $-0.004 * *$ & -0.005 & 0.0027 \\
\hline Monday & $0.0043 * *$ & $0.009 * * *$ & 0.003 & $0.010^{* * *}$ & $0.065 * * *$ \\
\hline$\sum \operatorname{Com}(0$ to -4$)$ & $0.0024 * * *$ & $0.0023 * * *$ & $-0.011^{* * *}$ & $0.032 * * *$ & $0.038 * * *$ \\
\hline US News & $-0.0056^{* *}$ & -0.002 & 0.005 & -0.0029 & $-0.0085^{* * *} *$ \\
\hline Dum011707 & & & & $0.487 * * *$ & \\
\hline Dum081507 & $-1.23 * * *$ & $-1.15^{* * *}$ & & $-1.22 * * *$ & \\
\hline Dum121505 & $0.73^{* * *}$ & $0.76^{* * *}$ & $0.697 * * *$ & & \\
\hline Dum042406 & $0.52 * * *$ & $0.38^{* * *}$ & $0.439 * * *$ & & \\
\hline Dum051005 & & & $0.436^{* * *}$ & & \\
\hline Dum042506 & & & $-0.232 * * *$ & & \\
\hline Dum042613 & & & & & $-1.39 * * *$ \\
\hline Dum032408 & & & & & $-0.384 * * *$ \\
\hline Intervention & & & & & 0.0114 \\
\hline \multicolumn{6}{|l|}{ Variance } \\
\hline$\eta$ & $0.004 * * *$ & $0.005 * * *$ & $0.0021^{* * *}$ & $* 3.85$ & $-0.579 * * *$ \\
\hline$\lambda \operatorname{Resid}(-1)$ & & & & 0.13 & $-0.174 *$ \\
\hline$\beta(-1)$ & $0.202^{* *}$ & & & 0.327 & $0.925 * * *$ \\
\hline$\alpha(-1)$ & $0.124 * *$ & 0.089 & $0.801 * * *$ & $0.339^{* *}$ & $0.433 * * *$ \\
\hline GED & $0.585^{* * *} *$ & $0.608 * * *$ & $0.64 * * *$ & $0.726 * * *$ & $0.824 * * *$ \\
\hline Adj R2 & 0.420 & 0.384 & 0.446 & 0.460 & 0.224 \\
\hline $\mathrm{AR}(10)$ & $8.07[0.62]$ & $9.01[0.53]$ & $4.21[0.93]$ & $8.07[0.62]$ & $10.75[0.37]$ \\
\hline $\mathrm{ARCH}$ & $0.66[0.41]$ & $0.87[0.35]$ & $0.21[0.64]$ & $0.83[0.36]$ & $0.28[0.59]$ \\
\hline
\end{tabular}

*** Z-statistic significant at $1 \%$ level (** 5\%;* 10\%). This corresponds to the estimation of equation (5) and (2) or (3) in the text with corresponding definitions of variables and parameters. 
Table A.3.4. Repo change (Log Close minus log Open rate) with surprise component of policy rate

\begin{tabular}{|c|c|c|c|c|c|}
\hline & $\begin{array}{c}\text { 02 Jan 2005-21 } \\
\text { Jan } 2008 \\
\end{array}$ & $\begin{array}{c}\text { 02 Jan 2005-12 } \\
\text { Sept 2008 } \\
\end{array}$ & $\begin{array}{c}\text { 02 Jan 2005-05 } \\
\text { May 2006 } \\
\end{array}$ & $\begin{array}{l}\text { 06 May 2006-12 } \\
\text { Sept 2008 } \\
\end{array}$ & $\begin{array}{c}15 \text { Jan 2009-27 } \\
\text { Aug 2013 } \\
\end{array}$ \\
\hline \multicolumn{6}{|l|}{ Mean } \\
\hline Cst & $-0.0056^{* * *}$ & $-0.098 * * *$ & $0.008 * * *$ & $-0.019 * *$ & $-0.012 * * *$ \\
\hline$\sum \mathrm{AR}$ (1 to $\left.\mathrm{n}\right)$ & $0.054 * * *(5)$ & $0.046^{* * *}(6)$ & $0.165^{* * *}(7)$ & $-0.022 * * *(7)$ & $0.175^{* * *}(6)$ \\
\hline Macro & -0.0011 & 0.0003 & $-0.0099 * * *$ & -0.002 & 0.0021 \\
\hline Surprise & 0.0029 & 0.024 & 0.0247 & 0.055 & $0.248 * * *$ \\
\hline NETA & $6.76 \mathrm{E}-07 * * *$ & $-3.45 \mathrm{E}-07 * *$ & $-1.33 \mathrm{E}-06^{* * *}$ & $-8.35 \mathrm{E}-09^{* * *}$ & $1.02 \mathrm{E}-07 * * *$ \\
\hline Friday & $-0.0067 * * *$ & $-0.005 * * *$ & $-0.006^{*}$ & $-0.005^{* *}$ & 0.0012 \\
\hline Monday & $0.0045^{* * *}$ & $0.0062 * * *$ & 0.0023 & $0.0088^{* * *}$ & $0.0071 * * *$ \\
\hline$\sum \operatorname{Com}(0$ to -4$)$ & $0.007 * *$ & $0.065^{* * *}$ & $0.0075^{*}$ & $0.018 * * *$ & $0.038 * * *$ \\
\hline US News & -0.0009 & $-0.005^{* * * *}$ & 0.007 & $-0.0066^{*}$ & $-0.0069^{*}$ \\
\hline Dum011707 & & & & $0.488 * * *$ & \\
\hline Dum081507 & $-1.16^{* * *}$ & $-1.23 * * *$ & & $-1.23 * * *$ & \\
\hline Dum121505 & $0.71 * * *$ & $0.73 * * *$ & $0.725^{* * *}$ & & \\
\hline Dum042406 & $0.34 * * *$ & $0.34 * * *$ & $0.419 * * *$ & & \\
\hline Dum051005 & & & $0.442 * * *$ & & \\
\hline Dum042506 & & & $-0.233 * * *$ & & \\
\hline Dum042613 & & & & & $-0.973^{* * *}$ \\
\hline Dum032408 & & & & $-0.576^{* * *}$ & \\
\hline Intervention & & & & & $0.0153 *$ \\
\hline \multicolumn{6}{|l|}{ Variance } \\
\hline$\eta$ & $0.002 * * *$ & $0.005 * * *$ & $-6.19 * * *$ & -3.22 & $-0.7814 * * *$ \\
\hline$\lambda \operatorname{Resid}(-1)$ & & & & & $-0.063 * * *$ \\
\hline$\beta(-1)$ & $0.515^{* *}$ & & & 0.410 & $0.896 * * *$ \\
\hline$\alpha(-1)$ & $0.103^{* *}$ & 0.102 & $0.663 * * *$ & 0.212 & $0.317 * * *$ \\
\hline GED & $0.588^{* * * *}$ & $0.621 * * *$ & $0.739 * * *$ & $0.659^{* * *}$ & $0.820 * * *$ \\
\hline Adj R2 & 0.418 & 0.376 & 0.461 & 0.497 & 0.210 \\
\hline $\mathrm{AR}(10)$ & $5.38[0.86]$ & $6.94[0.73]$ & $4.93[0.89]$ & $10.73[0.37]$ & $11.3[0.330]$ \\
\hline $\mathrm{ARCH}$ & $0.73[0.39]$ & $0.86[0.35]$ & $0.06[0.80]$ & $1.03[0.31]$ & $0.001[0.96]$ \\
\hline
\end{tabular}

*** Z-statistic significant at $1 \%$ level (** 5\%; *10\%). This corresponds to the estimation of equation (5) and (2) or (3) in the text with corresponding definitions of variables and parameters. In the sample 02 Jan 2005-05 May 2006 only the sum of advances from 1 to 5 of Com are significant, suggesting probably expectations on the communication.

\section{Copyrights}

Copyright for this article is retained by the author(s), with first publication rights granted to the journal.

This is an open-access article distributed under the terms and conditions of the Creative Commons Attribution license (http://creativecommons.org/licenses/by/4.0/). 